\title{
BioéthiqueOnline
}

\section{Pain Viewed from the Outside: A Response to Verpaelst}

\section{Kadija Perreault}

Volume 4, 2015

Reçu : 9 Jul 2015; publié : 18 Sept 2015; éditeurs : Aliya Affdal \& Jean Poupart; travail creatif discuté: F. Verpaelst. A Pain In My

NeckBioéthiqueOnline 2015, 4/10

URI : https://id.erudit.org/iderudit/1035510ar

DOI : https://doi.org/10.7202/1035510ar

Aller au sommaire du numéro

Éditeur(s)

BioéthiqueOnline

ISSN

1923-2799 (numérique)

Découvrir la revue

Citer cet article

Perreault, K. (2015). Pain Viewed from the Outside: A Response to Verpaelst BioéthiqueOnline, 4. https://doi.org/10.7202/1035510ar
Résumé de l'article

La douleur est une expérience subjective. Tenter de comprendre le quotidien des personnes vivant avec la douleur est important pour les cliniciens, les professeurs et les chercheurs. Être exposé(e) à des oeuvres d'art créées par des personnes qui vivent avec la douleur est une façon d'aider à comprendre ces expériences vécues. 


\title{
Pain Viewed from the Outside: A Response to Verpaelst
}

\author{
COMMENTAIRE / COMMENTARY \\ Kadija Perreault ${ }^{1,2}$
}

Reçu/Received: 9 Jul 2015

Éditeurs/Editors: Aliya Affdal \& Jean Poupart

Publié/Published: 18 Sept 2015

Travail creatif discuté/Creative Work discussed: F. Verpaelst. A Pain In My Neck BioéthiqueOnline 2015, 4/10

2015 K Perrault, Creative Commons Attribution 4.0 International License

\section{Résumé}

La douleur est une expérience subjective. Tenter de comprendre le quotidien des personnes vivant avec la douleur est important pour les cliniciens, les professeurs et les chercheurs. Être exposé(e) à des œuvres d'art créées par des personnes qui vivent avec la douleur est une façon d'aider à comprendre ces expériences vécues.

Mots clés

douleur, physiothérapie, perceptions, éducation sur la douleur, art

\section{Summary}

Pain is a subjective experience. Gaining insight from persons in pain into what it is to live with pain is important for clinicians, teachers and researchers. Being exposed to art created by persons in pain is one way to help understand these lived experiences.

\section{Keywords}

pain, physiotherapy, perceptions, pain education, art

Affiliations des auteurs / Author Affiliations

${ }^{1}$ Centre interdisciplinaire de recherche en réadaptation et intégration sociale (CIRRIS), Québec, Canada

${ }^{2}$ Département de réadaptation, Faculté de médecine, Université Laval, Québec, Canada

\section{Correspondance / Correspondence}

Kadija Perreault, kadija.perreault@fmed.ulaval.ca

\section{Conflit d'intérêts}

Aucune déclaré

\section{Conflicts of Interest}

None declared

\section{Preamble}

As an Assistant Professor in the Department of Rehabilitation (Faculty of Medicine) at Université Laval, I teach about pain to physiotherapy students and conduct research in the area of health services for persons experiencing pain. I was initially drawn to research because my first years of practice working with persons experiencing pain and work-related disability generated numerous questions, such as how can I help and enjoy my work as a physiotherapist? Reading and appreciating Verpaelst's painting and words [1] reminded me of my journey until now. But most of all, it reminded me to never forget the importance of the actual experiences of persons in pain: what I view from the outside never equates with what is lived from the inside.

\section{Commentary}

Some might say that I know pain because I am a physiotherapist who practiced for about ten years. Pain, often defined as "an unpleasant sensory and emotional experience associated with actual or potential tissue damage, or described in terms of such damage" [2], was the main reason persons consulted me as a professional. I became especially interested in pain after my first year in practice, as a junior clinician who struggled with pain management and what is now described as the complex biopsychosocial nature of pain and mainly chronic pain. As a physiotherapy student, I had been taught to understand pain mostly according to the biomedical model, a model that asserts that pain is directly attributable to specific pathology [3]. While this model was often applicable in my work, it didn't help me understand why some persons developed chronic pain in the absence of severe physical pathology or damage and how all kinds of factors can influence one's experience of pain, including 
personal factors, such as previous experiences of pain or trauma, as well as environmental factors, for example, those associated with living and working conditions [4]. Faced with such complexity and having a limited toolbox, going home at night after a day full of being in contact with people in pain was not always easy. I wanted to know more, do a better job and feel better about my work. So, after my second year of practice, I travelled abroad to obtain a Postgraduate Diploma in Pain. During this program, I had plenty of "ah-ha" moments and I came back home a year later feeling enthused, more knowledgeable and more confident in my role. Still, I didn't know pain.

Some might also say that I know pain because I am a researcher in the area of health services for persons experiencing pain and because I am a university professor who's been teaching physiotherapy students the subject for several years. As a junior researcher, I hope to pursue meaningful research that addresses important issues for persons in pain, for their families and for those who contribute to their care. As a teacher, I try to provide better training than what I had received on the subject, because the importance of teaching about pain was not as recognized as it is today, having increasingly been discussed in Canada around the mid 2000s [5,6]. Overall guidance on what content should be included in clinical training for future professionals working with persons experiencing pain is now also much more developed than when I was a trainee. Still, I don't know pain.

I don't know pain like someone who wakes up day after day with rigid and achy limbs, a burning face or the sensation of being stabbed in the back; someone who will face the whole day trying to turn down the volume in any way that works, at least partially, also trying to do things without triggering further pain and suffering. I've had aches and pains in different areas of my body every now and then, for a few hours, a few days or a few weeks at the most. I don't know pain.

Arguably, I may not have to know pain personally to teach it, research it or attempt to treat it. But at least, I have to recognize it and acknowledge that what is visible may not reflect the actual experience of someone in pain. What we see in others is tainted by what we know, what we've done, what we've felt. There is no exception for health professionals. Yes, we embody professionalism, expertise and knowledge, but we are also human; and we take with us in the consultation room who we are as professionals and as persons, at least partially. For health professionals, pain can be viewed as a challenge $[7,8]$. This can lead to misjudgement regarding what is reported or expressed by someone experiencing pain. Our perceptions and emotions can also influence our interventions [9] and clinical reasoning [10].

As a teacher, I have been trying to implement strategies to help myself and my students know pain better, so that as professionals, we have a better understanding of this multidimensional phenomenon and what experiencing pain on a daily basis may be. One of these strategies has been to invite a person experiencing severe chronic pain to come to class to discuss her experience. Every year, several students mention that having the chance to hear a person's story is very revealing for them and helps break down stereotypes and misbeliefs about living with pain. I have also been presenting pictures of artwork created by persons experiencing pain. One of them is a painting made by Radene Marie-Cook that was also published in 2011 in the Journal of Pain and Palliative Care Pharmacotherapy. The artist called her work Divided Soul as this expresses the "dilemma that every chronic and intractable pain patient is forced to deal with: the socially acceptable face we present in public and the private horror going on inside, behind the smile" [11, p.111]. This resonates with Frank Verpaelst's [1] words regarding his experience of pain and hiding his pain inside to prevent from being judged and excluded by others because of his pain.

Textbooks, scientific articles and communications certainly are essential sources for gaining an understanding of pain and what to do about it. But as a clinician, teacher, researcher and person, art also helps me know pain. Reading a poem, looking at a picture or a painting created by someone in pain is a way for me to better imagine what he or she is experiencing. The emotions elicited by 
looking at a drawing of a disfigured face, Frank Verpaelst's [1] A Pain in my neck or Frida Khalo's Broken column [12], somehow gives me a hint of what a person in pain may be feeling, something that should never be overshadowed.

\section{List of References}

1. Verpaelst F. (2015) A Pain in My Neck. BioéthiqueOnline, 4/10

2. International Association for the Study of Pain. Pain. Washington; 2012.

3. Asmundson G, Gomez-Perez L, Richter A, Carleton RN. The psychology of pain: models and targets for comprehensive assessment. Chapter 4 in: Hubert van Griensven (ed.), Pain: A Text Book for Health Professionals. Elsevier; 2014. p. 35-48.

4. Sluka KA. Mechanisms and Management of Pain for the Physical Therapist. Seattle: International Association for the Study of Pain; 2009. 411 p.

5. Watt-Watson J, Hunter J, Pennefather P, Librach L, Raman-Wilms L, Schreiber M, et al. An integrated undergraduate pain curriculum, based on IASP curricula, for six health science faculties. Pain. 2004;110(1-2):140-8.

6. Watt-Watson J, McGillion M, Hunter J, Choiniere M, Clark AJ, Dewar A, et al. A survey of prelicensure pain curricula in health science faculties in Canadian universities. Pain Res Manag. 2009;14(6):439-44.

7. Marchand S. Le phénomène de la douleur. 2e ed. Montréal: Chenelière Éducation; 2009.

8. Lynch ME, Craig KD, \& Peng P. (2011). The challenge of pain: A multidimensional phenomenon. In Lynch ME, Craig KD, \& Peng P. Clinical Pain Management: A Practical Guide. Oxford, UK: Wiley-Blackwell Press. p. 3-5

9. Coll MP, Gregoire M, Latimer M, Eugene F, Jackson PL. Perception of pain in others: implication for caregivers. Pain Manag. 2011;1(3):257-65.

10. Langridge N, Roberts L, Pope C. The role of clinician emotion in clinical reasoning: Balancing the analytical process. Man Ther. 2015.

11. Marie-Cook R. Pain-The divided soul. J Pain Palliat Care Pharmacother. 2011;25(2):111.

12. Frida Khalo. Broken column (1944). Fridakahlo.org, 2011. 